\title{
Quest Back about The Integrity of Incumbent Regional Head to be Nominee in Different Region
}

\author{
Charlyna S. Purba ${ }^{1}$, Joko Martono ${ }^{2}$, Rini Setiawati ${ }^{3}$ \\ Faculty of Law Panca Bhakti University, Pontianak \\ charlyna.purba@gmail.com
}

\begin{tabular}{ll}
\hline Keywords : & ABSTRACT \\
integrity, regional head, & Regional head and vice regional head are selected to be a \\
nominee & leader in Indonesian region as Indonesian Local \\
Government Law. In their campaign, they promote their \\
visions, missions, and work program if they were selected \\
as regional head and vice regional head. In fact, they \\
nominate and nominated to be a regional head candidate \\
and vice regional head candidate in the same region and \\
even different region for the next election before they were \\
able to prove their integrity in their promises. Whereas, \\
their integrity is a guarantee for democratic goals to local \\
autonomy implementation the region got. It caused by the \\
legal vacuum as found in this issue. The study recommends \\
a legislation revision for Article 7 of 10 ${ }^{\text {th }}$ Governor, \\
Regent, and Mayor Election Law of 2016, the pairs of \\
regional head candidate requirement should have a \\
specific provision that the newly elected regional head \\
an/or vice regional head cannot be a nominee as regional \\
head candidate and/or vice regional head candidate before \\
their length of service is finished.
\end{tabular}

\section{INTRODUCTION}

After the independence of the Republic of Indonesia, governmental reforms were marked by the regulation on the regional head election in the Unitary State of the Republic of Indonesia based on Pancasila and the 1945 Constitution of the State of the Republic of Indonesia. The main objective of regional government reform according to Local Government Law is to accelerate people's welfare through improving services, empowerment, and community participation, enhancing regional competitiveness by taking into account the principles of government democracy, justice, privilege and specificity, increasing efficiency and effectiveness by taking into account inter-governmental and inter-governmental arrangements, regional potentials and globalization.

Since 1948, Local Government Law changed. However, the direct electoral mechanism by the people was applied after the legitimation of $22^{\text {nd }}$ Local Government Law of 1999 (Pemerintah Republik Indonesia, 1999), replaced by $32^{\text {nd }}$ Local Government Law of 2004 (Pemerintah Republik Indonesia, 1973). The up to date Local Government Law last modified by $9^{\text {th }}$ Local Government Law of 2015 regarding the Amendment of $23^{\text {rd }}$ Local Government Law of 2014 on Local Government (Pemerintah Republik Indonesia, 2015). 
The people directly determine who will be their local head and vice of local head in their each region. Of course, in determining their choice, the people will judge the qualities of the best candidate of leaders they would choose. Over 100 years, leadership research has yielded a strong evidence (Behrendt, Matz, \& Göritz, 2017). Some of the unique challenges faced in leading research studies (Divala, Mungwira, \& Laufer, 2015), (Chabeli, Malesela, \& Nolte, 2016), (Matei \& Camelia, 2016), (Krylova, Jolly, \& Phillips, 2017), (Kairouz, El, \& El, 2016) were discussed about integrity.

Integrity was believed is one of the important things to measure the leader's quality. Brown (Borovac, Peronja, \& Russo, 2012) opinions regarding leadership characteristic as: competence, dynamism, integrity, empathy, responsibility, personal style, political skills, episodic judgement, social background, political position.

My focus is the question of the pair of regional head integrity. In fact, many elected regional head could not prove their integrity as they said in their vision, mission and work program. In this paper, I propose an analysis of ruling integrity in Local Government Law. Related to the candidate of the regional head issue, integrity becomes a determinant of leader's success, including the elected regional head in the success of local autonomy.

\section{METHOD}

The type of the research is dogmatic legal research. The phase of research is exploratory research through the unstructured method and then hypothesis building. Data were collected by qualitative. The purpose of the study is to explore the question about the regional head candidate and/or vice regional head candidate integrity as they are nominees in a different region. The scope of the research is Indonesia Law related to the local election.

\section{RESULTS AND DISCUSSIONS}

\section{A. Local Democracy through Local Election}

Sovereignty adopted by Indonesia based on the 1945 Constitution of the Republic of Indonesia (Sekretariat-Negara-RI, 2002) is the sovereignty of the people as well as the rule of law as referred to Article 1 paragraph (2) stated "Sovereignty is in the hands of the people and is implemented according to this Constitution". Besides of state agencies, state sovereignty is also carried out by the people themselves through general elections, one of them is to choose regional head and the vice of regional head as governor/vice governor who will order in province, regent/vice regent who will order in district and mayor/vice mayor who will order in city based on Article 18 paragraph (4) 1945 Constitution of the Republic of Indonesia (Sekretariat-Negara-RI, 2002).

It is expected that the elected regional heads are in accordance with the common will of the community based on the vision, mission, work program, quality and integrity of the candidate. Later, the regional head election result is very important for the implementation of regional autonomy, because the elected regional head is the prime mover of the success of the local government realization of the governance based on the principle of local autonomy.

Local autonomy is the right, authority, and obligation of autonomous regions to regulate and manage their own governmental affairs and interests of the local community in the system of the Republic of Indonesia (Pemerintah RI, 2014). The authority given in its implementation is led by the regional head as the highest leader at the regional level. That is why, local autonomy implementation is part of the local democracy (Choi, 2007). Local democracy (Pratchett, 2004) provides more than simply the opportunity for individuals to influence those decisions that affect their immediate social and economic environment. It also builds and reinforces notions of participatory citizenship, because it is the primary venue in which most people practice politics. Strong local autonomy is essential to maintaining the local democracy practices that underpin broader democratic cultures within the polity (Pratchett, 2004). 


\section{B. No Prohibition Rules to be a Candidate of Regional Head for Incumbent}

A democracy government is by the people; we mean that the people collectively do things-elect leaders (Dworkin, 1995). The regional head will be the pioneer in the success of the regional autonomy implementation since all policies in the area are passed by the head of the region concerned. In the end, it has an impact and influence on the regional development and the improvement of people's welfare.

However, in its development the vision, mission, and program of the elected regional head previously presented in the campaign during the electoral process is merely a mere nonsense. All of these are presented only to entice people to win the election. In fact, the elected regional head was not really willing to serve in the area where he was elected leader. It is proved by some of the heads of newly elected and inaugurated regional heads in an area then volunteered as one of the candidate pairs of regional heads in different areas.

First, Karolin Margaret Natasa and Herculanus Heriadi are Landak Regent and Vice Regent period 2017-2022 who were inducted on $22^{\text {th }}$ May of 2017. Then, Chairman of Partai Demokrasi Indonesia Perjuangan Megawati Soekarno Putri officially announced Karolin Margaret Natasa as a candidate of Kalimantan Barat Governor a few weeks ago exactly on $7^{\text {th }}$ January of 2018. She is paired with Suryadman Gidot as Candidate of Kalimantan Barat Vice Governor. If we observed, vulnerable time of inauguration as regional head (Landak Regent) until the announcement is not up to 8 (eight) months yet. That was a very short time to prove her visions, missions, and work program she told in her campaign period of time.

Second, Mustafa is Lampung Tengah Regent period 2016-2021. He won the election in jointly regional head election on $9^{\text {th }}$ December of 2015 ago. Currently, he is accompanied by Loekman Djoyo as Lampung Tengah Vice Regent. Chusnuniah Chalim or Nunik is Lampung Timur Regent, she also won in the same time with Mustafa. Recently, Chusnuniah Chalim is accompanied by Arinal Djunaidi. They are fighting to win the seat as Kalimantan Barat Governor and Vice Governor in 2018.

Third, Emil Elistianto Dardak is Trenggalek District (Kabupaten) Local Head. He is elected through jointly regional head election on $9^{\text {th }}$ December of 2015 ago and inaugurated on $15^{\text {th }}$ February 2016. Nowadays, he nominates as Jawa Timur Province Vice Governor to accompany Khofifah Indar Parawansa. Their versus is Syaifullah Yusuf as Jawa Timur Province Governor Candidate and Abdullah Azwar Anas which is Banyuwangi Regent as Jawa Timur Province Vice Governor Candidate.

The three examples above are happening because there is no specific regulation prohibited the regional head and vice regional head nominate and nominated to be a regional head candidate and vice regional head candidate in the same region or even in the different region.

Article 7 of $1^{\text {st }}$ Government Regulation in Lieu of Law of 2014 on Governor, Regent and Mayor Election (Pemerintah Republik Indonesia, 2014a) contains "Indonesian citizen who may be a candidate of governor, candidate of regent, and candidate of mayor shall fulfill the following requirements: (1) be cautious of Almighty God; (2) faithful to Pancasila, 1945 Constitution of the Republic of Indonesia, the ideals of $17^{\text {th }}$ August of 1945 Proclamation of Independence, and the Unitary State of the Republic of Indonesia; (3) the lowest education is senior high school or equivalent; (4) has followed the Public Test; (5) the lowest ages are 30 (thirty) years old for Candidate of Governor and 25 (twenty five) years old for Candidate of Regent and Candidate of Mayor; (6) being capable of physically and spiritually based on the result of comprehensive medical examination from doctor; (7) has never been sentenced based on a court decision with permanent legal force for committing a crime which is punishable by imprisonment of at least 5 (five) years long or more; (8) is not being revoked of the right to vote based on a court decision that has had permanent legal force; (9) has never committed a disgraceful act; (10) submit a list of personel wealth; (11) is not in possession of any individual debt and/or legal entity which is his/her liability which is detrimental to the state's finances; (12) is not being declared bankrupt based on a court decision having a permanent legal force; 
(13) has Tax ID Number and personel tax report; (14) has never served as Governor, Regent, Mayor for two periods for the same position; (15) resigns from his/her position as Governor, Regent, Mayor who nominate their selves in other region; (16) is not acting as Governor officials, Regent officials, and Mayor officials; (17) has no conflict interest with the incumbent; (18) notify his/her nominee as Governor, Regent and Mayor to the Chairman of the House of Representatives (Dewan Perwakilan Rakyat) for members of the House of Representatives, to the Chairman of Regional Representative Council (Dewan Perwakilan Daerah) for members of Regional Representative Council, or to the Chairman of Regional People's Representative Assembly (Dewan Perwakilan Rakyat Daerah) for members of Regional People's Representative Assembly; (19) resign as a member of Indonesian National Army (Tentara Nasional Indonesia), Police of the Republic of Indonesia (Kepolisian Negara Republik Indonesia), and Government Employees (Pegawai Negeri Sipil) since enrolled as a candidate; and (20) resign from their position in state-owned enterprises or regional-owned enterprises.

Then, this provision ratified as Law based on $1^{\text {st }}$ Determination of $1^{\text {st }}$ Government Regulation in Lieu Law of 2014 of 2015. Latest, it is modified by $10^{\text {th }}$ Governor, Regent and Mayor Election Law of 2016. Article $710^{\text {th }}$ Governor, Regent and Mayor Election Law of 2016 is modified, so it states: (1) Every citizen has the right to get the same chance to be elected and nominated as Candidate of Governor and Candidate of Vice Governor, Candidate of Regent and Candidate of Vice Regent, Candidate of Mayor and Candidate of Vice Mayor; (2) Candidate of Governor and Candidate of Vice Governor, Candidate of Regent and Candidate of Vice Regent, Candidate of Mayor and Candidate of Vice Mayor as stated in paragraph (1) must fullfill the following requirements: (a) be cautious of Almighty God; (b) faithful to Pancasila, 1945 Constitution of the Republic of Indonesia, the ideals of $17^{\text {th }}$ August of 1945 Proclamation of Independence, and the Unitary State of the Republic of Indonesia; (c) the lowest education is senior high school or equivalent; (d) deleted; (e) the lowest ages are 30 (thirty) years old for Candidate of Governor and Candidate of Vice Governor and 25 (twenty five) years old for Candidate of Regent and Candidate of Vice Regent and Candidate of Mayor and Candidate of Vice Mayor; (f) being capable of physically, spiritually and free from drugs abuse based on the result of comprehensive medical examination from the whole team; (g) has never been convicted based on a court decision with permanent legal force or for ex-convict has been overt and honest declare to the public that she/he is an ex-convict; (h) she/he is not being revoked based on a court decision who already got permanent legal force; (i) has never done disgraceful act which proved by police sertificate; (j) submit a list of personel wealth; (k) not being in dept personally and/or legal entity which her/his responsibility which is detrimental to state finances; (l) not being declared bankrupt based on a permanent legal force court decision; (m) have Tax ID Number and personel tax report; (n) has never served as Governor, Vice Governor, Regent, Vice Regent, Mayor and Vice Mayor for two periods in the same position for Candidate of Governor, Candidate of Vice Governor, Candidate of Regent, Candidate of Vice Regent, Candidate of Mayor and Candidate of Vice Mayor; (o) has never served as Governor for Candidate of Vice Governor, or Regent/Mayor for Candidate of Regent/Candidate of Vice Mayor in the same region; (p) resign from his/her position for Governor, Vice Governor, Regent, Vice Regent, Mayor and Vice Mayor who nominee in other region since appointed as candidate; (q) is not acting as Governor official, Regent official, and Mayor official; (r) deleted; (s) stating resignation in writing as member of House of Representatives (Dewan Perwakilan Rakyat), members of Regional Representative Council (Dewan Perwakilan Daerah), and member of Regional People's Representative Assembly (Dewan Perwakilan Rakyat Daerah) since appointed as the pair of candidate of election; (t) stating resignation in writing as member of Indonesian National Army (Tentara Nasional Indonesia), Police of the Republic of Indonesia (Kepolisian Negara Republik Indonesia), and Government Employees (Pegawai Negeri Sipil) and Village Head (Kepala Desa) or another term since appointed as as the pair of candidate of election; and (u) Resign from his/her position in state-owned enterprises or local-owned enterprises since appointed as candidate.

Article 70 of $10^{\text {th }}$ of Regional Head Election Law of 2016 states as the following: (1) During the campaign, the pairs of candidate is prohibited to involve: (a) an officer of state-owned enterprises/local-owned enterprises; (b) state civil agency, member of Police of the Republic of Indonesia (Kepolisian Negara Republik Indonesia), and member of Indonesian National Army 
(Tentara Nasional Indonesia); and (c) village head or other term/headmen (lurah) and village set or other term/headmen set. (2) Governor and Vice Governor, Regent and Vice Regent, Mayor and Vice Mayor, another state official, and the local official can participate in the campaign by applying for campaign permission in accordance with the law provisions. (3) Governor and Vice Governor, Regent and Vice Regent, Mayor and Vice Mayor, who re-nominated in the same region, during the campaign period must fulfill the following requirements: (a) Taking a leave beyond the state responsibility; and (b) is prohibited to use facilities related to his/her position. (4) Taking a leave, referred to paragraph (3) for Governor and Vice Governor is given by Minister of Home Affairs on behalf of the President, and for Regent and Vice Regent, Mayor and Vice Mayor are given by District/City General Election Commission.

Based on the terms, no available provision specify the pairs candidate of the regional head and vice regional head are prohibited in submitting themselves as the pair of the regional head during they are still incumbent or still served, no matter it is in the same region or even in the different region. Absolutely, this is a legal vacuum. It will give space for the regional head candidate and vice regional head candidate to propose themselves as during their length of service.

There are two patterns of the regional head candidate and vice regional head candidate if they propose themselves during their length of service: First the regional head candidate and vice regional head candidate who nominate and nominated in the same region will be susceptible of authority abuse. Authority abuse (Pemerintah Republik Indonesia, 2014b) is an agency or government official in making the decision an/or actions in the administration of government carried out by exceeding authority, confusing authority, and/or acting arbitrarily.

Second, the regional head candidate and vice regional head candidate who nominate and nominated in the different region will leave their region. Of course, they will only consent all their election preparations in another region. it can not be denied that the regional head candidate and vice regional head candidate who nominate and nominated in the different region will forget all about their visions, missions, and work programs what they ever said to the community in the region during their campaign period.

Therefore, the outline is "integrity". The passion of regional head and vice regional head who nominate and nominated in the same region can not beyond the limits of their authority. In another side, there is a new trend, it is where the regional head and vice regional head who just served in a region but then the regional head and/or vice regional head nominate and nominated themselves to be a regional head and/or vice regional head candidate in the different region. Whereas, they have not done anything else in the region to prove their vision, mission and work program since were elected as regional head and/or vice regional head. But, then they are trying to fight again in the different region to be a regional head and/or vice regional head.

\section{Integrity is The Most Important Thing in Regional Head Nomination}

Integrity refers to the extent to which a trustee is perceived to adhere to a set of acceptable principles. It is also a cognitive indicator of trustworthiness and contributes to cognition-based trust (Hafiz, Azizal, \& Mohd, 2015). Means, someone integrity will make other people trust. The integrity is presumed to be linked to numerous values-related constructs including ethnics, morality, honesty, and sincerity (Krylova et al., 2017). Those ethnics, morality, honesty, and sincerity related to effective leadership. Leadership (Slimane, 2015) is organizing a group of people to achieve a common goal. Leadership has been described as the process of social influence in which one person can enlist the aid and support of others in the accomplishment of a common task. Leadership skills are also important for the success of innovative leadership, like Atatürk, Mahatma Gandhi, Martin Luther King Jr. (Eren, 2012), and others utilized values such as human rights, dignity, liberty, equality, fraternity, independence, security, morality, loyalty, creativity, happiness, honesty, integrity, trust, and courage.

The qualities needed by the leaders are as follows (Arif, Daud, Asmiran, \& Hassan, 2011): (1) strong determination (2) integrity (3) boldness (4) Perseverance (5) Ambition (6) Creativity (7) Imagination 
(8) Curiosity (9) Originality and (10) Contribution to others. Others opinion, Angelica-Nicoleta Onea and Maria Tatarusanu (Onea \& Tatarusanu, 2012) stated that charismatic/value-based as one of leadership dimension that reflects the ability to inspire, to motivate, and expect high-performance outcomes from others on the basis of firmly held core values. It labeled subscales are visionary, inspirational, self-sacrifice, integrity, decisive, and performance oriented. Finally, Ole B oe (Boe, Bang, \& Nilsen, 2015) found there were 12 character strengths were selected as the most important for leadership. These were in ranked order: leadership, integrity, persistence, bravery, open-mindedness, fairness, citizenship, self-regulation, love of learning, social intelligence, perspective, and creativity.

Based on all of the definitions above, prove that integrity is one of the most important things in leadership success (Monzani, Ripoll, \& Peiró, 2015). Related to the leadership of regional head and vice regional head who nominate and nominated as a regional head candidate and/or vice regional head candidate in the same or in the different region give us an extremely complicated question about it. Are they have lost their integrity?

Regional head and vice regional head who nominate and nominated as a regional head candidate and/or vice regional head candidate has been trifle away the community trust for them as the highest local leaders in their region. Beside of that, all their visions, missions, and work programs they said during the campaign period were as if a huge lie.

It is the proof that the regional head and vice regional head who nominate and nominated as a regional head candidate and/or vice regional head candidate did not depart with the right intention. Indeed, in their vision, missions and work programs they ever said in their campaign as if they appear for and on behalf of the interests of the people, but in the end they only want to build up the power. It can be seen, no longer after they were elected as the regional head and vice regional head, they have not done and prove anything to the community, but then they nominate and nominated as a regional head candidate and/or vice regional head candidate in another region.

Actually, the community hopes the society welfare will be brought by the regional head and vice regional head in their local government implementation as every region got their local autonomy. But, if the elected regional head and vice regional head have not done anything are nominating and nominated in another region will not be able to implement the local autonomy. these chances because of the main reason, namely the absence of a prohibition the pairs of a regional head candidate who has just served as regional head to nominate or nominated as a regional head candidate and/or vice regional head candidate for the next election in different area. In the light of Jointly Local Head Election will be done by 171 (one hundred and seventy-one) regions on $27^{\text {th }}$ June of 2018 . The question about the regional head candidate and vice regional head candidate integrity is still on and on.

\section{CONCLUSION AND SUGGESTION}

In conclusion, we can say that regional head and vice regional head integrity who nominate and nominated as a regional head candidate and/or vice regional head candidate is a serious problem. In addition, the pairs candidate integrity is a guarantee the achievement of democratic goals. Whereas, no available specific law regarding serving/incumbent regional head and/or vice regional head to be the nominee. The main recommendation is a legislation revision for $10^{\text {th }}$ Governor, Regent, and Mayor Election Law of 2016, especially Article 7 which contains the pairs of regional head candidate requirements. There is should be an addition specific provision mention: "The newly elected regional head an/or vice regional head cannot be a nominee as a regional head candidate and/or vice regional head candidate before their length of service is finished".

\section{ACKNOWLEDGEMENT}

Research for this paper was supported by Faculty of Law Panca Bhakti University. We also say thanks to our lovely family and friends for all the supports and loves. Nevertheless, the authors are fully responsible for any errors or omissions. 


\section{REFERENCES}

Arif, I., Daud, A., Asmiran, S., \& Hassan, Z. (2011). Development of educational leadership in research university through community of practices among professors. Procedia - Social and Behavioral Sciences, 15, 828-832. https://doi.org/10.1016/j.sbspro.2011.03.193.

Behrendt, P., Matz, S., \& Göritz, A. S. (2017). An integrative model of leadership behavior. Leadership Quarterly, 28(1), 229-244. https://doi.org/10.1016/j.leaqua.2016.08.002.

Boe, O., Bang, H., \& Nilsen, F. A. (2015). Experienced military officer' s perception of important character strengths. Procedia - Social and Behavioral Sciences, 190(1877), 339-345. https://doi.org/10.1016/j.sbspro.2015.05.008.

Borovac, S., Peronja, I., \& Russo, A. (2012). Linking theory with practice: Students perceptions of leaders and leadership characteristics, 41, 237-242. https://doi.org/10.1016/j.sbspro.2012.04.027.

Chabeli, M. M., Malesela, J. M. L., \& Nolte, A. G. W. (2016). ScienceDirect Best practice during intrapartum care: A concept analysis. Health SA Gesondheid, 22, 9-19. https://doi.org/10.1016/j.hsag.2016.07.006.

Choi, N. (2007). Local elections and democracy in indonesia: The Riau Archipelago. Journal of Contemporary Asia, 37(3), 326-345. https://doi.org/10.1080/00472330701408650.

Divala, T. H., Mungwira, R. G., \& Laufer, M. K. (2015). Moving targets: The challenges of studying infectious diseases among pregnant women in resource limited settings. Vaccine, 33(47), 64016405. https://doi.org/10.1016/j.vaccine.2015.08.042.

Dworkin, R. (1995). Constitutionalism and Democracy. European Journal of Philosophy, 3(1), 2-11. https://doi.org/10.1111/j.1468-0378.1995.tb00035.x.

Eren, E. (2012). Innovative Leadership for the Twenty-First Century, 41, 1-14. https://doi.org/10.1016/j.sbspro.2012.04.001.

Hafiz, M., Azizal, M., \& Mohd, F. (2015). Integrity Systems in Malaysian Public Sector: An Empirical Finding. Procedia Economics and Finance, 28(April), 260-265. https://doi.org/10.1016/S2212-5671(15)01109-0.

Kairouz, A., El, J., \& El, U. (2016). Sustainability of Public Management in the Developing Countries: the Case of Lebanon. Procedia - Social and Behavioral Sciences, 221, 378-387. https://doi.org/10.1016/j.sbspro.2016.05.133.

Krylova, K. O., Jolly, P. M., \& Phillips, J. S. (2017). Followers a $€^{\mathrm{TM}}$ moral judgments and leaders $\hat{\mathrm{a}} €^{\mathrm{TM}}$ integrity-based transgressions : A synthesis of literatures. The Leadership Quarterly, 28(1), 195-209. https://doi.org/10.1016/j.leaqua.2016.10.002.

Matei, A., \& Camelia, G. (2016). Characteristics of process management in the public institutions in Romania . Comparative analysis. Procedia Economics and Finance, 39(November 2015), 94101. https://doi.org/10.1016/S2212-5671(16)30246-5.

Monzani, L., Ripoll, P., \& Peiró, J. M. (2015). Ganando la mente y el corazón de los seguidores: El efecto interactivo de las competencias emocionales de los seguidores y el tipo de establecimiento de metas sobre la confianza en el líder. Revista Latinoamericana de Psicologia, 47(1), 1-15. https://doi.org/10.1016/S0120-0534(15)30001-7.

Onea, A., \& Tatarusanu, M. (2012). Cultural specificity and leadership. Procedia - Social and Behavioral Sciences, 3(12), 746-751. https://doi.org/10.1016/S2212-5671(12)00224-9.

Pemerintah Republik Indonesia. Undang-Undang Republik Indonesia Nomor 32 Tahun 2004 tentang Pemerintahan Daerah (1973).

Pemerintah Republik Indonesia. Undang-Undang Republik Indonesia Nomor 22 Tahun 1999 tentang Pemerintahan Daerah (1999). https://doi.org/10.1017/CBO9781107415324.004.

Pemerintah Republik Indonesia. Peraturan Pemerintah Republik Indonesia Nomor 1 Tahun 2014 tentang Pemilihan Gubernur, Bupati dan Walikota (2014).

Pemerintah Republik Indonesia. Undang-Undang Republik Indonesia Nomor 30 Tahun 2014 tentang Administrasi Pemerintahan (2014).

Pemerintah Republik Indonesia. Undang-Undang Republik Indonesia Nomor 9 Tahun 2015 tentang Perubahan Kedua Atas Undang-Undang Nomor 23 Tahun 2014 tentang Pemerintahan Daerah (2015).

Pemerintah RI. Undang-Undang Nomor 23 Tahun 2014 tentang Pemerintahan Daerah (2014). 
Pratchett, L. (2004). Local autonomy, local democracy and the 'new localism'. Political Studies. https://doi.org/10.1111/j.1467-9248.2004.00484.x

Sekretariat-Negara-RI. The 1945 Constitution of the Republic of Indonesia, $1 \S$ (2002). https://doi.org/10.1017/CBO9781107415324.004.

Slimane, M. (2015). Relationship between Innovation and Leadership. Procedia - Social and Behavioral Sciences, 181, 218-227. https://doi.org/10.1016/j.sbspro.2015.04.883. 